\title{
Financial Versus Sports Performance: The Missing Link
}

\author{
Luca Ferri $^{1}$, Riccardo Macchioni ${ }^{1}$, Marco Maffei ${ }^{1} \&$ Annamaria Zampella ${ }^{1}$ \\ ${ }^{1}$ Department of Economics, Management, Institutions, University of Naples Federico II, Italy \\ Correspondence: Luca Ferri, Department of Economics, Management, Institutions, University of Naples \\ Federico II, Italy. E-mail: alessandra.allini@unina.it
}

Received: January 20, 2017

doi:10.5539/ijbm.v12n3p36

\begin{abstract}
This paper aims to investigate the relationship between the financial and the sports performance of Italian football teams. To achieve this aim, a panel data analysis was performed, using financial statements and data from sports results. The panel dataset covers seven seasons (from 2007-2008 to 2013-2014) and 29 clubs that belong to the Italian "Serie A." The results indicate positive effects between the expenses for football players' salaries and the clubs' sports performance but no significant effects between player transfer fees and sports performance.
\end{abstract}

Keywords: sports manager, financial performance, sports performance

\section{Introduction}

"Your goal shouldn't be to buy players.

Your goal should be to buy wins and,

in order to buy wins, you need to buy your run"(Money-ball, 2011).

This paper aims to provide an understanding of how different performance logics influence a particular field of study, such as football teams. All kinds of organizations are required to "perform" and to communicate their achievements to key stakeholders. This can be a simple activity when firms have just one performance logic to follow (i.e., profit maximization) but becomes more complex in contexts with several performance logics. The need to establish links between different logics and to understand how they influence each other and what managers should do to increase firm performance has generated considerable interest in measurement and performance studies. Indeed, management accounting and performance researchers have examined a wide range of issues related to performance logics and performance measurement systems (PMSs) and their designs (e.g., Goold \& Quinn, 1990; Hall, 2008; Henri, 2006; Ittner, Larcker, \& Meyer, 2003).

The main theoretical motivation for this present research comes from a set of recent studies examining the difficulties of management when two or more performance logics coexist (Carlsson-Wall, Kraus, \& Messner, 2016) in a specific sector, such as medical (de Halez \& Malagueño, 2016; King, Clarkson, \& Wallace, 2010), public (MacBryde, Paton, Bayliss, \& Grant, 2014; Modell, 2003; Poister, 2008), and financial (Lonsbury, 2007; Zhang, 2014). Lonsbury (2007) investigated how trustee and performance logics (based on different locations) resulted in mutual funds' varied approaches to setting up contracts with independent professional money management firms. Lonsbury discussed this issue in the context of the dominant two-stage institutional model.

Chenhall, Hall, and Smith (2013) also showed that different performance logics could influence each other and required varied PMSs to provide an understanding of the firms' results. The authors stated that the coexistence of different performance logics could create a positive effect on firms' degree of performance for the benefit of all shareholders.

The logics discussed in this paper are those of the sports sector, specifically football. In this regard, many authors have emphasized that football clubs are subject to different performance logics that can influence each other (e.g., Smith \& Steward, 2010). This paper particularly refers to sports and financial performance logics.

Football teams should take into account two kinds of performance. On one hand, they should consider the need for high sports performance; on the other hand, they should reach the expected levels of economic and financial performance to ensure their going concern. This paper aims to shed light on how these different performance logics coexist in Italian football teams, how they influence each other, and how football managers should 
manage them. Specifically, financial performance refers to a series of budget goals, to the achievement of competitive balance, to debt reduction, or generally, to the maximization of shareholders' interests. In contrast, sports performance is related to a club's need to achieve success in the competitions in which it participates during the season. The coexistence of these two performance logics in the football sector has been widely recognized in the literature (Carlsson-Wall et al., 2016; Dimitropoulos \& Limperopoulos, 2014; Dimitropoulos, 2014; Szymanky, 1998). Szymanky (1998) showed that the performance of sports clubs had two distinct components: the envisioned sports results (sports performance) and the firms' financial and economic goals (financial performance). The author believed that the dominant logic for clubs should necessarily be the sports one because without satisfactory sports performance, clubs would fail in achieving their financial goals. This situation could create financial instability that would end with the clubs' downfall. Sloane (1971) and Kesenne (2007) focused on the economic performance of the sports clubs. These authors contended that despite the coexistence of different logics of dominant performance, the financial one should prevail. This argument was based on a club's need to obtain the required financial resources to ensure smooth operations even before a sporting competition.

In their recent study, Carlsson-Wall and colleagues (2016) examined different methodologies of the management of the coexistence of different institutional logics in football organizations. They showed that if sports and business logics competed with each other over a long period, it would be possible to create harmony because their ambiguous cause-effect relationship would allow for different ways of enacting the logics. The authors thus demonstrated that the compatibility of logics might vary, not just among different countries and firms but also across diverse situations within the same club.

Notably, in situations with a single performance logic (e.g., financial performance), an accurate measurement system can provide an idea of the efficiency level of firms. Indeed, the existence of a single logic simplifies management choices and eliminates all the tradeoff problems, making it possible for managers to carry out specific actions (or action plans) to correct adverse market developments or improve current levels. However, when different performance logics coexist, choices are considerably more difficult to make and require a different way of reasoning. It is no longer possible to identify the best action (or a set of best actions), but it becomes necessary to find a fair tradeoff among different logics to ensure their right coexistence. How football managers decide to behave in these situations, how to set firms' priorities, and how to find the right tradeoff among different logics are poorly treated subjects (Goold \& Quinn, 1990; Hall, 2008; Henri, 2006; Ittner et al., 2003; Lonsbury, 2007). In this regard, the sports field (specifically, football) represents an under-explored context; thus, two important questions emerge. How does financial performance influence sports performance in football teams? How should football managers handle the different performance logics?

This paper aims to explore the relations among the main financial variables that affect sports performance in order to explain which actions should (or should not) be taken by football managers to create a harmonious coexistence among different performance logics. To achieve this aim, we perform an empirical analysis based on panel data to verify how the different financial variables interact with sports performance.

This paper contributes to the existing literature on sports and financial performance by showing the effects of economic and financial variables on clubs' performance. To our best knowledge, this is the first study in the Italian Serie A setting that attempts to distinguish among the significant determinants of sports performance. Thus, our study adds to the growing body of research on sports performance. Overall, we show the existence of a strong positive relation between return on investment (ROI) and salary cost. This work also reveals a low negative relation between sports performance and investment in football players. Moreover, this study responds to several researcher's call for further studies concerning the financial results of football clubs and relation with sports performance (Dimitropoulos, 2009, 2010; Lago, Simmons, \& Szymanski, 2006). We aim to show how financial performance affects sports performance in order to explain which actions should (or should not) be taken by football managers to create a harmonious coexistence among different performance logics.

The rest of this paper is organized as follows. Section 2 covers the model's background and development. Section 3 shows the model used, the variables' descriptions, and the data collection. Section 4 discusses the research results in the light of previous literature. Section 5 presents the conclusions, along with possible avenues for future research.

\section{Model's Development}

Recently, several researchers examined how different performance logics would affect firms' performance (Almandoz, 2012, 2014; Besharov \& Smith, 2014; Reay \& Hinings, 2009) and how they could coexist (Besharov \& Smith, 2014; Lounsbury, 2007; Marquis \& Lounsbury, 2007; Reay \& Hinings, 2005). Other scholars tried to 
explore the link between financial and sports performance in different sports (Barros, 2006; Dimitropoulos \& Limperopoulos, 2010, 2014; Lago et al., 2006). For example, Dimitropoulos and Limperopoulos (2014) examined the relation between sports performance and investment in player contracts in Greek football clubs. The authors found that those clubs with higher investments in player contracts also attained greater success in their competitions. Moreover, increasing the football players' salaries made the clubs unprofitable and insolvent, suggesting that investment decisions in Greece were not based on economic logics. Other authors attempted to explain the link between financial instability and the performance level of football clubs (Barros, 2006; Boscà, Liern, Martínez, \& Sala, 2008; Dimitropoulos, 2009, 2010; Lago et al., 2006). For example, Rezende, Dalmacio, and Facure (2010) and Kesenne (2010) found a positive relationship between financial instability and sports performance. The authors concluded that this was the main reason why the overwhelming majority of the European football clubs had financial difficulties or huge financial debts.

The purpose of this research is to highlight the existence of a link between the amount of money invested by the companies participating in the Italian Serie A and the actual sporting performance over a seven-year period (from the 2007-2008 to the 2013-2014 season). Specifically, we aim to describe the effects of investments, players' fees, salaries, cash flow, income, and other variables (economic, financial, and governance) - that have been found significant in the literature - on the sports performance of clubs.

Undoubtedly, professional football clubs should reach two different levels of performance (Szymanski \& Kuypers, 1999). First, clubs (as all professional sports associations) are formed to win or to obtain a suitable placement in national competitions (Szymanski \& Kuypers, 1999). Football clubs try to score the maximum number of points during a season to achieve a suitable level of sports performance. Second, clubs are limited companies (or corporations) that should ensure a good level of profits for their shareholders. The debate about football clubs' performance has two different (but connected) aspects (Szymanski \& Kuypers, 1999). Indeed, football clubs try to achieve their preset sports goals in order to realize positive financial performance and vice versa. Therefore, the coexistence of these performance logics makes the management of clubs particularly difficult. To understand how financial performance affects sports performance, we develop a model by using the variables described in the following subsections.

\subsection{Sports Performance Definition}

Sports performance can be defined as a club's ability to obtain a high number of victories in the competitions in which it participates (Garcia-del-Barrio \& Szymanski, 2009). Thus, a club has high sports performance when it achieves high scores in these competitions. Indeed, the results are influenced by a huge number of variables (endogenous and exogenous), such as the players' personal and cultural values (Denzin, 2003; Ono, Kennedy, Reeves, \& Cronin, 2012), the club management's ability to define and reach sports goals through appropriate decisions (Heiji et al., 2006; Ozawa, Cross, \& Henderson, 2004), individual player attributes (Gerrard, 2005), the coach's skills (Dawsona \& Dobson, 2002; Koning, 2003), the club's market size, the number of supporters (Pinnuck \& Potter, 2006), and the casualty of the game (Boscà et al., 2008; Carmichael, Thomas, \& Ward, 2000). Clearly, the sports results are related to the existence of an appropriate corporate structure that is able to regulate all of these variables. This paper aims to study how economic, financial, and governance variables affect sports performance. We consider as a dependent variable the points collected by the clubs in every season divided by the maximum number of available points.

\subsection{Income and Sports Performance}

Sports performance can significantly depend on a firm's income (Houston \& Wilson, 2002; Simons, 2000; Szymanski, 1998, 1999). As noted in prior studies, the impact of monetary investments on business performance has been widely researched in different disciplines and the majority of these studies have found that monetary investments generally have positive impacts on short- and long-term performance of the businesses (Aghdaie et al., 2012; Riasi and Pourmiri, 2015; Suh et al., 2013).

First, there are many differences between the results within a short period and those occurring over medium and long terms. According to several authors, within a short period, a club's ability to maintain a high level of financial performance depends on the revenue from the transfer fees for the most important players (Bruggink \& Rose, 1990; Deloitte, 2015), the number of supporters (Cleland, 2010; Wolfson, Wakelin, \& Lewis, 2005), the pay-TV rights (Andreff \& Bourg, 2006; Ascari \& Gagnepain, 2006; Baroncelli \& Lago, 2006), the effectiveness of the marketing campaign, and the number of games played (Houston \& Wilson, 2002; Rösch et al., 2000). Based on this argument, in the short period, it is easier for the firm's management to focus on the financial performance logic of that sport. Over the medium and the long terms, the financial logic appears related to sports; a club that often wins is more popular and earns more revenue from merchandising, pay-TV rights, and the 
premium earned by the federations (Andreff \& Bourg, 2006; Ascari \& Gagnepain, 2006; Baroncelli \& Lago, 2006; Houston \& Wilson, 2002).

In this regard, several authors tried to explain the link between sports performance and profits over short and long terms. For example, using an OLS model, Arnold (1991) showed that the performance level of English clubs was closely associated with their sports performance. As a result, the clubs that earned more profits had lower sports performance. However, the limitation of Arnold's research was the short period used to collect the data. Szymanski (1998) also examined the correlation between 40 English clubs' profit levels before taxes and the sports results in the following years. The author found a strong and positive relationship between the variables. A satisfactory sports performance allowed clubs to earn higher revenues in subsequent years, leading to positive profits (Szymanski, 1998; Szymanski \& Kuypers, 1999). However, it should be noted that Szymanski found a negative relation between sports performance and profits. Therefore, it seems acceptable to sacrifice the financial logic in the short period to achieve greater returns in medium to long terms.

On the other hand, other authors found a strong positive relation between football club size and the degree of sports performance (Szymanski and Smith, 2010). Clubs with more resources had higher financial performance. Szymanski and Smith (2010) showed that larger clubs were also those with higher sports performance in the English Premier League. Based on previous literature, the first and the second hypotheses can be stated as follows:

H1. Club profits negatively affect sports performance.

H2. Club size positively affect sports performance.

\subsection{Salary Costs and Sports Performance}

Salary represents the most important cost in the balance sheet of football teams. Dimitropulos and Limperopulos (2014) examined the relationship between sports performance and salary in Greek football clubs. Specifically, the authors analyzed the impact of investments in players' contracts on sporting performance over a five-year period (from the 2004-2005 to the 2008-2009 season). In cases with higher investments in players' salaries, there was also an increased degree of sports performance. On the other hand, this kind of investment made a football club less profitable, so an inverse relationship existed between financial performance and the performance of the sports clubs in Greece.

Through a linear regression analysis, Hall, Szymanski, and Zimbalist (2002) and Morrow (1999) previously attempted to demonstrate a causal link between players' remuneration and high sports performance. The authors explained the existence of a strong positive relation between the football players' salaries and their chances to win. However, other studies (e.g., Fort \& Quirk, 1995) showed that the link between sports performance and salaries could vary in both directions. Such studies did not take into account the effect of players' motivations during the different seasons, the football players' ages, and the governance variables. Based on this set of arguments, we present the third hypothesis:

H3. There is a strong positive relation between salary costs and sports performance.

\subsection{Football Player Fee and Sports Performance}

Recently, Hamil and Walters (2010) put forward the strong managerial implications of the coexistence of multiple performance logics in sports clubs. The researchers' analysis of the Premier League clubs' financial performance in 1992 revealed that notwithstanding the large increase in revenues, many clubs were unsuccessful in meeting all their short-term goals due to blunders in the target-setting process or wrong investments. Specifically, English clubs favored an increase in sports performance over financial logic. Club managers increased the level of investment in football players. They did not reach the desired level of sports performance and failed in their goals; this had a negative effect, leading to a significant growth in debt. The study indicated that all the teams that sacrificed financial logic to improve sports performance suffered from a negative effect, leading to a substantial increase in financial debt. Dobson and Goddard $(1998,2004)$ provided a detailed financial analysis of the professional English clubs in terms of the management's bargaining skills (increase in the players' salaries) and their effect on the performance of the English Premier League's teams. Their research showed a direct negative relation among a competitive financial statement, the clubs' rankings, and the consistency with the established sports objectives. The authors did not explain the causal link across different variables. More recently, Dimitropoulos and Limperopoulos (2014) found a strong positive relation between sports performance and investment in players' contracts. Based on this set of arguments, we formulate the fourth hypothesis:

H4. A positive relation exists between sports performance and investment in football players. 


\subsection{Financial Variables and Sports Performance}

Dobson and Goddard (1998) explored the relationship between sports performance and cash flow from operations (FCFO) (the cash flow generated by the box office) in the clubs that participated in the English Premier League. The authors found a positive relation between the variables in just 10 cases (from a total sample of 77), and this relationship existed mostly for small clubs (not for larger ones). Szymanski (2001) also showed that the increased degree of inequality in the revenues earned by small and large clubs did not change the level of competitiveness in the English clubs. The probability of winning or losing a game was not affected by economic recovery. Moreover, Haas (2003) and Haas, Kocher, and Sutter (2004) stated that the level of sports performance was not related to financial performance in Germany.

However, several studies demonstrated a connection between football clubs' investments and financial instability (Ascari \& Gagnepain, 2006; Barros, 2006; Boscà et al., 2008; Frick \& Prinz, 2006; Kesenne, 2010; Lago et al., 2006; Rezende et al., 2010). These authors stated that clubs with higher financial performance were those with higher leverage because managers accumulated substantial debts to invest in players' contracts or fees. Based on this set of arguments, we hypothesize the following:

\section{H5. A significant negative relation exists between FCFO and sports performance.}

H6. A significant positive relation exists between leverage and sports performance.

\subsection{Governance Factors and Sports Performance}

Several researchers stated that the prevalence of one performance logic over another depended entirely on the will of the managers who chose one main goal to pursue. In this regard, there are two opposing schools of thought.

Many authors argued that football clubs should try to pursue profit maximization, highlighting a classic agency problem due to the interests of two kinds of figures - the football managers and the proprietors (Dietl \& Franck, 2007; El Hodiri \& Quirk, 1974; Hassan \& Hamil, 2010; Lusted 2009; Scully, 1994). Indeed, on one hand, football managers try to maximize sports performance due to personal interests (they can have greater contractual power, maximize their salaries, etc.); on the other hand, shareholders want to maximize financial performance (Dietl \& Franck, 2007; El Hodiri \& Quirk, 1974; Hassan \& Hamil, 2010; Hope, 2003; Lusted, 2009). Thus, according to these authors, if a club has fewer shareholders (or the owners are from the same family), the goal will not be to maximize profits in the short term but to obtain more benefits in the middle-long term. As shown by several authors (Dobson \& Goddard, 2004; Gerrard \& Dobson, 2000; Morrow, 1999), clubs that are not family owned usually have greater sports performance than the others. This indicates the family proprietors' strong influence on the management's will to pursue sports performance rather than financial performance (Giulianotti \& Robertson, 2010), as well as a sort of family "control" on the management activities. Indeed, in the context where families have greater presence, managers have less liberty, or there is usually a problem with chief executive officer (CEO) duality. On the other hand, in the context with a lot of shareholders, managers exercise more freedom and try to maximize their own interests. According to Sloane (1971) and Kesenne (2007), clubs should maximize their utility in the pursuit of sports goals, leaving out profit and financial performance. Therefore, financial performance is just a constraint to be respected rather than a goal to be achieved. In this view, there is a coincidence of managers' interests and sports performance. Based on these two theories, Vrooman $(1997,2000)$ demonstrated how, in the absence of a restricted property, managers sought to combine the maximization of sports and economic results. The author proved that with a certain level of resources, clubs that tried to reconcile sporting and economic performance were able to achieve better results in both medium and long terms. Gerrard (2005) developed a similar model and arrived at the same conclusions. Based on this set of arguments, we present the following hypotheses:

H7. Family members in the board have a negative influence on sports performance.

\section{H8. We expect a negative effect of CEO duality and sports performance.}

\subsection{Other External Factors}

Several authors underlined the existence of different external influences on football teams' sports and financial performance (Gasquez \& Royuela; 2014; Yamamura, 2009). Considering different geographical areas, these studies took into account a set of macroeconomic variables that might vary (e.g., gross domestic product, unemployment, relationship between supply and demand, etc.). For example, Gasquez and Royuela (2014) stated that a direct connection existed between sports performance and a territory's economy. Specifically, football clubs in a rich country should have higher sports performance. This kind of study explained the differences in performance among clubs belonging to different territories. In this regard, our research does not consider such 
external macroeconomic variables because this study is localized in just one country (Italy) and in a single championship. Thus, the influences of those variables are not considered because they have the same effects for all the teams.

However, several studies demonstrated a significant performance difference, depending on the number of supporters. Indeed, followers who strongly support the football teams can create strong psychological effects on football players, increasing team performance (Cleland, 2010; Wolfson et al., 2005). According to this statement, we consider the mean number of team followers in the ninth hypothesis:

\section{H9. The average number of sports followers has a positive effect on the teams'sports performance.}

\section{Research Design and data Collection}

\subsection{Panel Data Analysis}

To test our hypotheses, we carried out a panel data analysis with fixed effects. We chose panel data due to several positive implications of this methodology. First, a panel dataset contains more information, with more variability and less collinearity among the different variables. Second, panel analysis provides more efficient estimates, and more precise parameters would allow us to identify many effects that would not be detectable in the cross-sectional data. This kind of analysis also allows us to study the variable dynamics, estimating how the companies' data would change over different time periods. Moreover, panel data analysis enables us to have better control over individual heterogeneity effects, studying the same set of variables in different time periods (individual heterogeneity) and providing a more accurate view of the phenomenon than the simple OLS model. Finally, to understand which kind of effect we should consider (fixed effect [FE] or random effect [RE] panel data), we carried out Hausman's (1978) test that suggested fixed effects $(p<0.05)$.

The empirical analysis proposal was based on the Italian Serie A data from the 2007-2008 to the 2013-2014 seasons. The sample comprised 140 observations. Next, we removed from the sample all the teams that participated in the competition for just one year (i.e., Pescara) and all the observations with missing data. The final sample consisted of 129 observations.

To reach our aim, first, we searched for suitable regression specifications to examine the relationship between sports performance in Italian football teams and financial performance. In this section, we present the empirical panel data analysis to test outcomes for a pooled regression with clustered robust standard errors (Rogers, 1993). The outcomes are compared with the possible alternatives - the RE and the FE models. We start with the following regression specifications:

$$
\begin{aligned}
P T_{i t}=\alpha+\beta_{1} R O I_{i t}+\beta_{2} S_{I Z E_{i t}}+ & \beta_{3} S A L A R Y_{i t}+ \\
+ & \beta_{4} I N V E S T M E N T_{i t}+\beta_{5} F C F O_{i t}+\beta_{6} L E V_{i t}+\beta_{7} B O A R D_{i t}+\beta_{8} C e o D_{i t} \\
& +\beta_{9} A F O L L_{i t}+\varepsilon
\end{aligned}
$$

The variables and their sources are explained in Table 1.

\begin{tabular}{|c|c|c|c|}
\hline $\begin{array}{l}\text { Variables' } \\
\text { Labels }\end{array}$ & Variables' Nature & Description & Data Source \\
\hline PT & Sports & $\begin{array}{l}\text { Obtained as the number of points scored by each football team in every } \\
\text { season divided by the maximum number of points }\end{array}$ & $\begin{array}{l}\text { Italian } \\
\text { Serie A }\end{array}$ \\
\hline ROI & Economic & $\begin{array}{l}\text { Return on investment estimated by dividing earning before interest and } \\
\text { taxes over total asset }\end{array}$ & $\begin{array}{l}\text { Amadeus } \\
\text { Databank }\end{array}$ \\
\hline SIZE & Economic & Natural logarithm of total asset & $\begin{array}{l}\text { Amadeus/AIDA } \\
\text { Databank }\end{array}$ \\
\hline SALARY & Economic & Total salary of football players & $\begin{array}{l}\text { Football teams Balance } \\
\text { sheet }\end{array}$ \\
\hline INVESTMENT & Economic & $\begin{array}{l}\text { Calculated as the difference between total fees earned from transferring } \\
\text { players and total fees paid for acquiring players }\end{array}$ & $\begin{array}{l}\text { Football teams Balance } \\
\text { sheet }\end{array}$ \\
\hline FCFO & Financial & Value of operating cash flow as reported in the cash flow statement & $\begin{array}{l}\text { Amadeus } \\
\text { Databank }\end{array}$ \\
\hline LEV & Financial & Obtained by dividing total debt by equity. & $\begin{array}{l}\text { Amadeus } \\
\text { Databank }\end{array}$ \\
\hline Board & Governance & $\begin{array}{l}\text { Obtained by dividing the number of family members in the board by the } \\
\text { total number of board members }\end{array}$ & $\begin{array}{l}\text { Football teams Balance } \\
\text { sheet }\end{array}$ \\
\hline
\end{tabular}

Table 1. Variables used in the model 


\begin{tabular}{llll}
\hline CeoD & Governance & Dummy variable, 1 if there is CEO duality & $\begin{array}{l}\text { Football teams Balance } \\
\text { sheet } \\
\text { Italian } \\
\text { AFOLL }\end{array}$ \\
External & Mean of the followers' presence in the stadium every year & Serie A \\
\hline
\end{tabular}

The data were collected by using two different databanks-AMADEUS and AIDA. In case of missing values, we used the balance sheets of the football teams or the documents provided by the Serie A (for example, to obtain the average number of followers). In total, there are 9 independent variables, broken down into 4 economic performance measures, 2 financial performance measures, 2 governance factors, and 1 external variable. Table 2 presents the descriptive statistics of the sample variables for the whole period of the investigation.

Table 2. Correlation coefficients among the sample variables

\begin{tabular}{|c|c|c|c|c|c|c|c|c|c|c|c|c|}
\hline & $\mathbf{P t}$ & ROI & $\begin{array}{l}\text { SALA } \\
\text { RY }\end{array}$ & $\begin{array}{l}\text { INVESTM } \\
\text { ENT }\end{array}$ & FCFO & LEV & Board & CeoD & SIZE & $\begin{array}{l}\text { AFOL } \\
\mathbf{L}\end{array}$ & Mean & $\begin{array}{l}\text { Standa } \\
\text { rd } \\
\text { error }\end{array}$ \\
\hline $\mathbf{P t}$ & 1 & & & & & & & & & & 54.11 & 1.43 \\
\hline ROI & 0.16 & 1 & & & & & & & & & -0.62 & 0.24 \\
\hline SALARY & -0.08 & -0.04 & 1 & & & & & & & & 0.15 & 0.04 \\
\hline $\begin{array}{l}\text { INVEST } \\
\text { MENT }\end{array}$ & -0.16 & -0.05 & 0.21 & 1 & & & & & & & 4.03 & 2.35 \\
\hline FCFO & -0.28 & 0.03 & 0.03 & 0.03 & 1 & & & & & & $\begin{array}{l}-33244 \\
49\end{array}$ & $\begin{array}{l}218153 \\
0\end{array}$ \\
\hline LEV & 0.27 & 0.20 & 0.35 & 0.26 & 0.12 & 1 & & & & & 0.43 & 0.09 \\
\hline Board & 0.09 & 0.17 & 0.19 & 0.18 & 0.08 & 0.08 & 1 & & & & 0.31 & 0.08 \\
\hline CeoD & 0.14 & 0.22 & 0.13 & -0.04 & -0.03 & -0.03 & 0.27 & 1 & & & 0.59 & 0.06 \\
\hline SIZE & $0.71 * * *$ & 0.12 & -0.18 & -0.12 & -0.19 & $0.49 * *$ & 0.32 & $0.31 * *$ & 1 & & 22.38 & 0.09 \\
\hline AFOLL & $0.62 * * *$ & 0.16 & -0.13 & -0.10 & -0.14 & 0.21 & 0.22 & 0.09 & $0.70 * * *$ & 1 & $\begin{array}{l}25692.0 \\
7\end{array}$ & 1237.63 \\
\hline
\end{tabular}

Notes: Figures with $(* *$ and $* * *)$ indicate $p$ values with a significance at the 0.01 level or less. The total sample comprised 39 football clubs participating in the first division of the Italian football league (Italian Serie A) in the selected period.

$\mathrm{Pt}=$ number of points earned by each football team in every season.

ROI $=$ return on investment estimated by dividing EBIT over total asset.

SALARY = salary variation between two years.

INVESTMENT $=$ difference between total fees earned and expenses arising from player transfers.

FCFO $=$ value of operating cash flow as reported in the cash flow statement.

$\mathrm{LEV}=$ ratio between total debt and equity.

BOARD $=$ ratio between family members in the board and the total number of board members.

$\mathrm{CeoD}=$ a dummy variable.

SIZE $=$ natural logarithm of total asset.

$\mathrm{AFOLL}=$ mean of the followers' presence in the stadium every year.

\section{Research Results and Discussion}

Table 3 summarizes the results of the panel data analysis. The regression is significant, with an overall R-square of 0.64 and F-test of $70.92(p>0.001)$. Notably, all coefficients have the predicted sign and are statistically significant. 
Table 3. Research results

\begin{tabular}{|c|c|c|c|c|}
\hline Number & Hypothesis & Variable & Coefficient & Findings \\
\hline H1 & Profits negatively affect sports performance. & ROI & 1.137 & $\begin{array}{l}\text { Not supported } \\
p<0.01\end{array}$ \\
\hline $\mathrm{H} 2$ & Size positively affect sports performance. & SIZE & 6.121 & $\begin{array}{l}\text { Supported } \\
p<0.001\end{array}$ \\
\hline H3 & $\begin{array}{l}\text { A strong positive relation exists between salary costs } \\
\text { and sports performance. }\end{array}$ & SALARY & 3.397 & $\begin{array}{l}\text { Supported } \\
p<0.01\end{array}$ \\
\hline $\mathrm{H} 4$ & $\begin{array}{l}\text { A positive relation exists between sports performance } \\
\text { and investment in football players. }\end{array}$ & INVESTMENT & 0.051 & $\begin{array}{l}\text { Supported } \\
p<0.1\end{array}$ \\
\hline H5 & $\begin{array}{l}\text { A significant negative relation exists between FCFO } \\
\text { and sports performance. }\end{array}$ & FCFO & -0.039 & $\begin{array}{l}\text { Supported } \\
p<0.001\end{array}$ \\
\hline H6 & $\begin{array}{l}\text { A significant positive relation exists between leverage } \\
\text { and sports performance. }\end{array}$ & LEV & 1.121 & $\begin{array}{l}\text { Supported } \\
p<0.01\end{array}$ \\
\hline $\mathrm{H} 7$ & $\begin{array}{l}\text { Family members on the board have a negative } \\
\text { influence on sports performance. }\end{array}$ & BOARD & -0.978 & $\begin{array}{l}\text { Supported } \\
p<0.001\end{array}$ \\
\hline H8 & $\begin{array}{l}\text { We expect a negative effect of CEO duality and sports } \\
\text { performance. }\end{array}$ & CEOD & -0.651 & $\begin{array}{l}\text { Supported } \\
p<0.01\end{array}$ \\
\hline H9 & $\begin{array}{l}\text { The average number of sports followers has a positive } \\
\text { effect on the teams' sports performance. }\end{array}$ & AFOLL & 0.05 & $\begin{array}{l}\text { Supported } \\
p<0.001\end{array}$ \\
\hline
\end{tabular}

With reference to profits (H1), the coefficient of ROI (1.137 with $p<0.01)$ is positive and statistically significant. This finding indicates that clubs with higher profitability are also those with higher sports performance. This also shows a situation of positive effects between sports performance and financial performance. According to our results, the two different performance logics can coexist, which does not support Arnold's (1991) argument that clubs must choose between sports and financial performance. This finding is relevant because we demonstrate the possibility of different performance logics' coexistence, confirming the conclusion of several authors (Besharov \& Smith, 2014; Lounsbury, 2007; Marquis \& Lounsbury, 2007; Reay \& Hinings, 2005).

As for $\mathrm{H} 2$, the coefficient of the SIZE variable is positive and statistically significant $(6.121$ with $p<0.001)$ as expected. This finding verifies our assumption that larger football clubs have greater sports performance since they are allowed to use economies of scale and to organize their activities more efficiently than small clubs. More specifically, this finding verifies our assumption about larger football clubs' higher sports performance because they can take advantage of economies of scale and more efficiently organized activities in comparison to small clubs. Also, this result confirms Szymanski and Smith's (2010) finding of a positive relation between a football club's size and sports performance.

Regarding football players' salaries, our results show a strong positive relation with sports performance, verifying H3 (SALARY $=3.397$ with $p<0.01$ ). Furthermore, a positive, strong, and significant relation exists between sports performance and the level of salaries paid to football players (3.397). This indicates that clubs paying higher salary levels can reach a higher level of sports performance in a short period. This conclusion supports previous research findings about a positive link between sports performance and players' salaries (Dimitropolous \& Limperopoulos, 2014; Wiseman \& Chatterjee, 2003). According to these authors, clubs that spend a great amount of money on salaries can dominate the competition. As result, $\mathrm{H} 3$ is fully supported.

Concerning the fees paid to buy out players contract (H4), a low positive relationship exists between the amount of money spent (INVESTMENT) and the level of sports performance reached by football clubs. Contrary to a previous argument (Dimitropoulos \& Limperopoulos, 2014), it can be stated that spending money on new players does not have a strong importance in improving football teams' sports performance. A possible explanation of this phenomenon could be that many times football managers spent more money in football players fee than their real values.

With reference to the financial variable, FCFO has a low negative effect on clubs' football performance (-0.039 with $p<0.001)$. Instead, leverage has a strong positive effect on sports performance $(1.121$ with $p<0.01)$. These findings confirm the results of Dimitropoulos (2010), Dimitropoulos and Limperopoulos (2014), and Lago and colleagues (2006); clubs with higher debts are able to reach higher levels of sports performance. These findings also explain why overinvesting in players' fees (increasing the debt level) has a positive effect on the sports performance of football clubs. As a result, $\mathrm{H} 5$ and $\mathrm{H} 6$ are supported. 
Regarding the governance variables, both the family presence in the board and CEO duality have negative effects on sports performance (BOARD $=-0,978$ with $p<0.001$; $\mathrm{CeoD}=-0.651$ with $p<0,01$ ). This finding confirms our hypothesis that a huge number of family members in the board reduce the degree of sports performance of clubs, especially when CEO duality also exists. More specifically, this finding reveal that, in the absence of a restricted property, managers sought to combine the maximization of sports and economic results. This statement is also compliant with the results of $\mathrm{H} 1$. As a result, $\mathrm{H} 7$ and $\mathrm{H} 8$ are both supported.

Finally, the average number of followers has a low positive effect on the performance of football teams (AFOLL $=0.05$ with $p<0,001$ ). This finding is compliant with Cleland's (2010) and Wolfson et al. (2005) arguments for the followers' strong psychological effects. However, the influences of this variable is residual. As a result, H9 is also supported.

\section{Conclusions}

This study responds to calls from further research who argue for the existence of a strong link between football clubs' financial results and sports performance (Dimitropoulos, 2009, 2010; Lago et al., 2006). We aim to show how financial performance affects sports performance in order to explain which actions should (or should not) be done by football managers to create a harmonious coexistence among different performance logics.

We find that the value of football players' annual salaries has a strong positive relation to the clubs' athletic success, measured as the number of points achieved in a single season. This finding confirms previous authors' arguments that clubs that spend more money on player talent can be more successful in the championship (Dimitropoulos, 2009; Frick \& Simmons, 2008; Hall et al., 2002). According to our results, it can be stated that football managers should invest more money on players' salaries (i.e., engage experienced players with no contract). Our analysis also reveals that teams with higher sports performance are those that spend more money on salaries than those that invest money on players acquisition. For clubs managers, it would thus be better to use the same amount of money to pay free-transfer players instead of buying out a contract from other clubs. A possible explanation for this phenomenon is that many times, the players available for free transfers are older and more experienced than their younger colleagues. However, player acquisition is sometimes not based on football merits but just on a marketing strategy (Dimitropoulos, 2010).

This paper contributes to the current literature in two ways. First, the evidence gathered from our research adds further knowledge about the relation between sports performance and financial performance, emphasizing financial and economic factors' greater impact on sports performance. Indeed, our analysis explains what main variables should be taken into account by football managers to find a fair tradeoff among different logics and to allow their harmonization. Second, this study offers a measurement of the causal effects of the different kinds of investment of football managers in terms of players' salaries or players' transfer fees. This allows practitioners to understand how to invest money in order to provide better sports performance in their own clubs.

The evidence offered in this study could be useful to football managers and regulators (i.e., the U.E.F.A. committee) for a couple of reasons. First, we provide professional football managers with an overview of the performance arising from different choices in the transfer market. Indeed, football clubs are motivated by athletic success instead of financial success, but there are different ways to spend the same amount of money, which provides clubs with different degrees of sports performance. Our results demonstrated that, in order to provide a good sport performance, it is important how managers spend money and not how much money they spend. So, sport managers should not decide between financial and sport performance: the two different logics can coexist. Second, this study could be valuable for regulators because with the same amount of money, it is possible to have different levels of performance, underlining the importance of how clubs spend money, not how much money they have.

This study has two limitations. First, football managers are not completely rational. They can decide for something irrational or not useful to the team. Second, this research is limited to the Italian Serie A, so the influence of our model's variables should be different in other football leagues.

Aside from these implications, other issues warrant further investigation. Future research may develop specific case studies or a multiple case study analysis to further observe the decision process in sports and financial performance management in order to understand how managers find the right tradeoff between them.

\section{References}

Aghdaie, S. F. A., Seidi, M., \& Riasi, A. (2012). Identifying the barriers to Iran's Saffron export by using Porter's diamond model. International Journal of Marketing Studies, 4(5), 129-138. https://doi.org/10.5539/ijms.v4n5p129 
Almandoz, J. (2012). Arriving at the starting line: The impact of community and financial logics on new banking ventures. Academy of Management Journal, 55(6), 1381-1406. https://doi.org/10.5465/amj.2011.0361

Almandoz, J. (2014). Founding teams as carriers of competing logics when institutional forces predict banks' risk exposure. Administrative Science Quarterly, 59, 442-473. https://doi.org/10.1177/0001839214537810

Andreff, W., \& Bourg, J. F. (2006). Broadcasting rights and competition in European football. The Economics of Sport and the Media, 37-70.

Arnold, A. J. (1991). An industry in decline? The trend in football league gate receipts. Service Industries Journal, 11(2), 179-188. https://doi.org/10.1080/02642069100000027

Ascari, G., \& Gagnepain, P. (2006). Spanish football. Journal of Sports Economics, 7(1), 76-89. https://doi.org/10.1177/1527002505282869

Baroncelli, A., \& Lago, U. (2006). Italian football. Journal of Sports Economics, 7(1), 13-28. https://doi.org/10.1177/1527002505282863

Barros, C. P. (2006). Portuguese football. Journal of sports economics, 7(1), 96-104. https://doi.org/10.1177/1527002505282870

Besharov, M. L., \& Smith, W. K. (2014). Multiple institutional logics in organizations: Explaining their varied nature and implications. Academy of Management Review, 39(3), 364-381. https://doi.org/10.5465/amr.2011.0431

Boscá, J. E., Liern, V., Martínez, A., \& Sala, R. (2008). The Spanish football crisis. European sport management quarterly, 8(2), 165-177. https://doi.org/10.1080/16184740802024476

Boscá, J. E., Liern, V., Martínez, A., \& Sala, R. (2009). Increasing offensive or defensive efficiency? An analysis of Italian and Spanish football. Omega, 37(1), 63-78. https://doi.org/10.1016/j.omega.2006.08.002

Bruggink, T. H., \& Rose Jr, D. R. (1990). Financial restraint in the free agent labor market for Major League Baseball: Players look at strike three. Southern Economic Journal, 1029-1043. https://doi.org/10.2307/1059889

Carlsson-Wall, M., Kraus, K., \& Messner, M. (2016). Performance measurement systems and the enactment of different institutional logics: insights from a football organization. Management Accounting Research. https://doi.org/10.1016/j.mar.2016.01.006

Carmichael, F., Thomas, D., \& Ward, R. (2000). Team performance: the case of English premiership football. Managerial and decision https://doi.org/10.1002/1099-1468(200001/02)21:1<31::AID-MDE963>3.0.CO;2-Q

Chenhall, R. H., Hall, M., \& Smith, D. (2013). Performance measurement, modes of evaluation and the development of compromising accounts. Accounting, Organizations and Society, 38(4), 268-287. https://doi.org/10.1016/j.aos.2013.06.002

Cleland, J. A. (2010). From passive to active: the changing relationship between supporters and football clubs. Soccer \& Society, 11(5), 537-552. https://doi.org/10.1080/14660970.2010.497348

Dawsona, P., \& Dobsonb, S. (2002). Managerial Efficiency and Human Capital: An Application to English. Managerial and Decision Economics, 23, 471-486. https://doi.org/10.1002/mde.1098

De Harlez, Y., \& Malagueño, R. (2016). Examining the joint effects of strategic priorities, use of management control systems, and personal background on hospital performance. Management Accounting Research, 30, 2-17. https://doi.org/10.1016/j.mar.2015.07.001

De Heij, R., Vermeulen, P., \& Teunter, L. (2006). Strategic actions in European soccer: Do they matter? The Service Industries Journal, 26(6), 615-632. https://doi.org/10.1080/02642060600850659

Deloitte (2015) Annual Review of Football Finance 2015. Retrieved from https://www2.deloitte.com/content/dam/Deloitte/it/Documents/consumer-business/CS\%20DTTL\%20Footb all\%20Finance\%202015\%20v2docx.pdf

Denzin, N. K. (2003). Performance ethnography: Critical pedagogy and the politics of culture. Sage. https://doi.org/10.4135/9781412985390

Dietl, H. M., \& Franck, E. (2007). Governance failure and financial crisis in German football. Journal of Sports Economics. https://doi.org/10.1177/1527002506297022 
Dimitropoulos, P. (2009). Analyzing the profitability of the Greek football clubs: Implications for financial decision making. Business Intelligence Journal, 2(1), 159-169.

Dimitropoulos, P. (2010). The financial performance of the Greek football clubs. Choregia, 6(1), 5-27. https://doi.org/10.4127/ch.2010.0042

Dimitropoulos, P. (2014). Capital structure and corporate governance of soccer clubs: European evidence. Management Research Review, 37(7), 658-678. https://doi.org/10.1108/MRR-09-2012-0207

Dimitropoulos, P. E., \& Limperopoulos, V. (2014). Player contracts, athletic and financial performance of the Greek football clubs. Global Business and Economics Review, 16(2), 123-141. https://doi.org/10.1504/GBER.2014.060181

Dobson, S. M., \& Goddard, J. A. (1998). Performance and revenue in professional league football: evidence from Granger causality tests. Applied Economics, 30(12), 1641-1651. https://doi.org/10.1080/000368498324715

Dobson, S., \& Goddard, J. (2004). Revenue divergence and competitive balance in a divisional sports league. Scottish Journal of Political Economy, 51(3), 359-376. https://doi.org/10.1111/j.0036-9292.2004.00310.x

El Hodiri, M., \& Quirk, J. P. (1974). An economic theory of a sports league. Government and the sports business, 33-80.

Fort, R., \& Quirk, J. (1995). Cross-subsidization, incentives, and outcomes in professional team sports leagues. Journal of Economic Literature, 33(3), 1265-1299.

Frick, B., \& Prinz, J. (2006). Crisis? What crisis? football in Germany. Journal of Sports Economics, 7(1), 60-75. https://doi.org/10.1177/1527002505282868

Frick, B., \& Simmons, R. (2008). The impact of managerial quality on organizational performance: evidence from German soccer. Managerial and Decision Economics, 29(7), 593-600. https://doi.org/10.1002/mde.1431

Garcia-del-Barrio, P., \& Szymanski, S. (2009). Goal! Profit maximization versus win maximization in soccer. Review of Industrial Organization, 34(1), 45-68. https://doi.org/10.1007/s11151-009-9203-6

Gásquez, R., \& Royuela, V. (2014). Is football an indicator of development at the international level?. Social indicators research, 117(3), 827-848. https://doi.org/10.1007/s11205-013-0368-x

Gerrard, B. (2005). A resource-utilization model of organizational efficiency in professional sports teams. Journal of Sport Management, 19(2), 143-169. https://doi.org/10.1123/jsm.19.2.143

Gerrard, B., \& Dobson, S. (2000). Testing for monopoly rents in the market for playing talent-Evidence from English professional football. Journal of Economic Studies, 27(3), 142-164. https://doi.org/10.1108/01443580010326049

Giulianotti, R., \& Robertson, R. (2004). The globalization of football: a study in the glocalization of the 'serious life'. The British Journal of Sociology, 55(4), 545-568. https://doi.org/10.1111/j.1468-4446.2004.00037.x

Goold, M., \& Quinn, J. J. (1990). The paradox of strategic controls. Strategic Management Journal, 11(1), 43-57. https://doi.org/10.1002/smj.4250110104

Haas, D. J. (2003). Productive efficiency of English football teams-a data envelopment analysis approach. Managerial and Decision Economics, 24(5), 403-410. https://doi.org/10.1002/mde.1105

Haas, D., Kocher, M. G., \& Sutter, M. (2004). Measuring efficiency of German football teams by data envelopment analysis. Central European Journal of Operations Research, 12(3), 251.

Hall, M. (2008). The effect of comprehensive performance measurement systems on role clarity, psychological empowerment and managerial performance. Accounting, Organizations and Society, 33(2), 141-163. https://doi.org/10.1016/j.aos.2007.02.004

Hall, S., Szymanski, S., \& Zimbalist, A. S. (2002). Testing causality between team performance and payroll the cases of major league baseball and english soccer. Journal of Sports Economics, 3(2), 149-168. https://doi.org/10.1177/152700250200300204

Hamil, S., \& Walters, G. (2010). Financial performance in English professional football:'an inconvenient truth'. Soccer \& Society, 11(4), 354-372. https://doi.org/10.1080/14660971003780214

Hassan, D., \& Hamil, S. (2010). Models of football governance and management in international sport. Soccer \& 
Society, 11(4), 343-353. https://doi.org/10.1080/14660971003780115

Hausman, J. 1978. Specification Tests in Econometrics. Econometrica, 46, 1251-1271. https://doi.org/10.2307/1913827

Henri, J. F. (2006). Management control systems and strategy: A resource-based perspective. Accounting, organizations and society, 31(6), 529-558. https://doi.org/10.1016/j.aos.2005.07.001

Hope, C. (2003). When should you sack a football manager? Results from a simple model applied to the English Premiership. Journal of the Operational Research Society, 54(11), 1167-1176. https://doi.org/10.1057/palgrave.jors.2601621

Houston, R. G., \& Wilson, D. P. (2002). Income, leisure and proficiency: an economic study of football performance. Applied Economics Letters, 9(14), 939-943. https://doi.org/10.1080/13504850210140150

Ittner, C. D., Larcker, D. F., \& Meyer, M. W. (2003). Subjectivity and the weighting of performance measures: Evidence from a balanced scorecard. The Accounting Review, 78(3), 725-758. https://doi.org/10.2308/accr.2003.78.3.725

Kesenne, S. (2007). The peculiar international economics of professional football in Europe. Scottish Journal of Political Economy, 54(3), 388-399. https://doi.org/10.1111/j.1467-9485.2007.00421.x

Kesenne, S. (2010). The financial situation of the football clubs in the Belgian Jupiler league: are players overpaid in a win-maximization league?. International Journal of Sport Finance, 5(1), 67.

King, R., Clarkson, P. M., \& Wallace, S. (2010). Budgeting practices and performance in small healthcare businesses. Management Accounting Research, 21(1), 40-55. https://doi.org/10.1016/j.mar.2009.11.002

Koning, R. H. (2003). An econometric evaluation of the effect of firing a coach on team performance. Applied Economics, 35(5), 555-564. https://doi.org/10.1080/0003684022000015946

Lago, U., Simmons, R., \& Szymanski, S. (2006). The financial crisis in European football an introduction. Journal of Sports Economics, 7(1), 3-12. https://doi.org/10.1177/1527002505282871

Lounsbury, M. (2007). A tale of two cities: Competing logics and practice variation in the professionalizing of mutual funds. Academy of Management Journal, 50(2), 289-307. https://doi.org/10.5465/AMJ.2007.24634436

Lusted, J. (2009). Playing games with 'race': understanding resistance to 'race'equality initiatives in English local football governance. Soccer \& Society, 10(6), 722-739. https://doi.org/10.1080/14660970903239941

MacBryde, J., Paton, S., Bayliss, M., \& Grant, N. (2014). Transformation in the defence sector: The critical role of performance measurement. Management Accounting Research, 25(2), 157-172. https://doi.org/10.1016/j.mar.2013.07.006

Marquis, C., \& Lounsbury, M. (2007). Vive la résistance: Competing logics and the consolidation of US community banking. Academy of Management Journal, 50(4), 799-820. https://doi.org/10.5465/AMJ.2007.26279172

Modell, S. (2003). Goals versus institutions: the development of performance measurement in the Swedish university sector. Management Accounting Research, 14(4), 333-359. https://doi.org/10.1016/j.mar.2003.09.002

Morrow, S. (1999). The new business of football: Accountability and finance in football. Springer. https://doi.org/10.1057/9780230371743

Ono, M., Kennedy, E., Reeves, S., \& Cronin, L. (2012). Nutrition and culture in professional football. A mixed method approach. Appetite, 58(1), 98-104. https://doi.org/10.1016/j.appet.2011.10.007

Ozawa, T., John, C., \& Steven, H. (2004). Market orientation and financial performance of English professional football clubs. Journal of Targeting, measurement and Analysis for marketing, 13(1), 78-90. https://doi.org/10.1057/palgrave.jt.5740134

Pinnuck, M., \& Potter, B. (2006). Impact of on-field football success on the off-field financial performance of AFL football clubs. Accounting and Finance, 46(3), 499-517. https://doi.org/10.1111/j.1467-629X.2006.00179.x

Poister, T. H. (2008). Measuring performance in public and nonprofit organizations. John Wiley \& Sons.

Reay, T., \& Hinings, C. R. (2009). Managing the rivalry of competing institutional logics. Organization studies, 
30(6), 629-652. https://doi.org/10.1177/0170840609104803

Rezende, A. J., Dalmacio, F. Z., \& Facure, C. E. F. (2010). Practice of corporate governance in football clubs. International Journal of Economics and Accounting, 1(4), 410-447. https://doi.org/10.1504/IJEA.2010.037579

Riasi, A., \& Pourmiri, S. (2015). Effects of online marketing on Iranian ecotourism industry: Economic, sociological, and cultural aspects. Management Science Letters, 5(10), 915-926. https://doi.org/10.5267/j.msl.2015.8.005

Rogers, W. (1994). Regression standard errors in clustered samples. Stata technical bulletin, 3(13).

Rösch, D., Hodgson, R., Peterson, L., Graf-Baumann, T., Junge, A., Chomiak, J., \& Dvorak, J. (2000). Assessment and evaluation of football performance. The American Journal of Sports Medicine, 28(suppl 5), S-29. https://doi.org/10.1177/28.suppl_5.s-29

Scully, G. W. (1994). Managerial efficiency and survivability in professional team sports. Managerial and Decision Economics, 403-411. https://doi.org/10.1002/mde.4090150503

Simmons, R. (2000). Performance measurement and control systems for implementing strategy. Upper Saddle River, New Jersey: Prentice-Hall.

Sloane, P. J. (1971). Scottish journal of political economy: the economics of professional football: the football club as a utility maximiser. Scottish Journal of Political Economy, 18(2), 121-146. https://doi.org/10.1111/j.1467-9485.1971.tb00979.x

Smith, A. C., \& Stewart, B. (2010). The special features of sport: A critical revisit. Sport Management Review, 13(1), 1-13. https://doi.org/10.1016/j.smr.2009.07.002

Suh, H., Van Hillegersberg, J., Choi, J., \& Chung, S. (2013). Effects of strategic alignment on IS success: the mediation role of IS investment in Korea. Information Technology and Management, 14(1), 7-27. https://doi.org/10.1007/s10799-012-0144-7

Szymanski, S. (1998). Why is Manchester United so successful?. Business Strategy Review, 9(4), 47-54. https://doi.org/10.1111/1467-8616.00082

Szymanski, S. (2001). Income inequality, competitive balance and the attractiveness of team sports: Some evidence and a natural experiment from English soccer. The Economic Journal, 111(469), 69-84. https://doi.org/10.1111/1468-0297.00599

Szymanski, S., \& Kuypers, T. (1999). Winners and losers. London: Viking.

Szymanski, S., \& Smith, R. (2010). The English football industry: profit, performance and industrial structure. In Football Economics and Policy (pp. 1-26). Palgrave Macmillan UK. https://doi.org/10.1057/9780230274266_1

Vrooman, J. (1997). A unified theory of capital and labor markets in major league baseball. Southern Economic Journal, 594-619. https://doi.org/10.2307/1061097

Vrooman, J. (2000). The economics of American sports leagues. Scottish Journal of Political Economy, 47(4), 364-398. https://doi.org/10.1111/1467-9485.00169

Wiseman, F., \& Chatterjee, S. (2003). Team payroll and team performance in major league baseball: 1985-2002. Economics Bulletin, 1(2), 1-10.

Wolfson, S., Wakelin, D., \& Lewis, M. (2005). Football supporters' perceptions of their role in the home advantage. Journal of Sports Sciences, 23(4), 365-374. https://doi.org/10.1080/02640410400021567

Yamamura, E. (2009). Technology transfer and convergence of performance: an economic study of FIFA football ranking. Applied Economics Letters, 16(3), 261-266. https://doi.org/10.1080/13504850601018361

Zhang, Y., Xia, J., \& Gong, Y. (2014, January). Analyst Pressure and Corporate Down-scoping: A Balanced-power Approach. In Academy of Management Proceedings (Vol. 2014, No. 1, p. 13158). Academy of Management. https://doi.org/10.5465/ambpp.2014.207

\section{Copyrights}

Copyright for this article is retained by the author(s), with first publication rights granted to the journal.

This is an open-access article distributed under the terms and conditions of the Creative Commons Attribution license (http://creativecommons.org/licenses/by/4.0/). 